\title{
Impact of Wastewaters on the Physico-Chemical Quality of Waters: Case Study of the Rhumel River, Hammam Grouz and Beni Haroun Dams
}

\author{
Meriem Melghit, Fatima Zohra Afri-Mehennaoui and Leila Sahli \\ Department of Biology and Ecology, University of Constantine, Constantine 25000, Algeria
}

\begin{abstract}
The primary objective of this study is to evaluate the physico-chemical qualities and the organic pollution of two dams-Hammam Grouz and Beni-Haroun, as well as that of Rhumel river. The latter, which feeds the dams is an important water source in the geographical region of the Constantinois. The presence of the stations of filtration and purification has not been sufficient to minimize the effect of the waste discharges released from various agglomerations. Five site points were selected in strategic locations where samples have been collected monthly during 2009. Multiple physico-chemical assessments have been conducted. The parameters determined have revealed that the quality of waters for the two dams is fair. The level of organic pollution is more pronounced in the waters of Hammam Grouz dam compared to that of Beni Haroun. This may be attributed to animal debris - very important organic content, which is a characteristic of the peripheral waters of the first dam (Hammam Grouz). On the other hand, the waters of the Rhumel river were assessed of mediocre quality, reflecting the presence of organic pollution.
\end{abstract}

Key words: Water, pollution, dam, river, quality.

\section{Introduction}

Water is the essential element of all life forms, and its pollution constitutes the biggest problem of the century. Consequently, many countries around the world, particularly the Mediterranean region are forced to cooperate in order to prevent the disastrous consequences that could result (climate change, aquatic ecosystems perturbations, etc.).

The Rhumel - an important river in the region of Constantine, is subject to great demographic and industrial demands due to the rapid expansion of urbanization and industries along the flow of its stream. It supplies Beni Haroun and Hammam Grouz dams, and the first dam alone supplies five provinces in the east of Algeria with potable water as well as irrigation water [1].

Corresponding author: Meriem Melghit, Ph.D. candidate, main research field: ecotoxicology.

\section{Presentation of the Zone of Study}

The zone of study is located in the catchment basin Kebir-Rhumel. Five sampling sites were selected in strategic locations, three in the Rhumel and two in the dams of Hammam Grouz and Beni Haroun. The basin of the Rhumel covers a surface area of approximately $5,315 \mathrm{~km}^{2}$. Rhumel river is located at $1,160 \mathrm{~m}$ in meridian marshes in the north of Belaa. The catchment basin is limited in the north by the lake Kebir, in the south by the basin of the high plains of Setif, in the east by the basin of the Seybousse, and in the west by the basin of Ennedja river. The average altitude of the lake is $806 \mathrm{~m}$.

The Rhumel flows in the nappe of the Tell of the mounts of Ferdjioua, which is characterized by its limestone with different geological formations which are composed of clay and gypsum base or marl and calcareous layers in a Mediterranean climate. It receives a minimal pluviometry rate of $30 \mathrm{~mm} /$ year in the south-east, and more than $1,500 \mathrm{~mm} /$ year in the 
north. The pluviometry rate exceeds $600 \mathrm{~mm} /$ year on one third of its surface.

\section{Material and Methods}

\subsection{Choice and Locations of Sample Collection Sites}

Rhumel - the most important river of the basin of Kebir-Rhumel, is the recipient of diverse discharges (urban, domestic and industrial) and supplies two major dams: Hammam Grouz and Beni Haroun upstream and downstream of the city of Constantine, respectively.

It is important to underline that the dam of Beni Haroun was put in operation in 2004 and has never been the subject of any study to evaluate its water quality. Five sites were selected for samples collection, testing and analysis: one site for each of the dams (Hammam Grouz and Beni Haroun) and three sites for Rhumel river.

- Site 1 (Bg1): Located at the level of Hammam Grouz dam and Athmania river. It takes into account the quality of waters destined for drinking water supply.

- Site $2(\mathrm{Rh} 2)$ : Located at Ain Smara at the level of the old bridge on the road of the new city Ali Mendjli. It serves as a site of reference upstream of the city of Constantine. At the same time, it permits the assessment of the effect of the municipality of Ain Smara on the Rhumel waters.

- Site 3 (Rh3): Located at the road of Constantine-Hamma Bouziane at the level of EL-Menia bridge. This site permits the evaluation of the quality of the waters of Rhumel river fed by the diffuse discharges and runoff waters. This site reflects the impact of an important agglomeration (Constantine) on the physico-chemical quality of the waters.

- Site 4 (Rh4): Located at the upstream of the confluence of Rhumel and Smendou rivers. It allows the evaluation of the quality of the waters, which feed the Beni Haroun dam.

- Site 5 (Rh5): Located at the level of Beni Haroun dam.
The samples have been collected once a month.

\subsection{Mode of Sample Collection}

The samples that were collected must be representative and obtained without altering the physico-chemical characteristics of the water (including dissolved gases, suspension material, etc.). The mode of collecting samples varies based on the type of the ecosystem.

In the case of a river, the collection of water samples must be performed in the middle of the running water bed in a depth of about $50 \mathrm{~cm}$ or at mid depth if the water level is less than $50 \mathrm{~cm} \mathrm{[2].}$

In the case of a dam, multiples points have been selected at different depths taking into account the vertical and horizontal heterogeneity.

\subsection{Methods}

\subsubsection{Temperature Measurement}

Temperature measurements have been performed in the field using a graduated thermometer 1/10 adhering to the rules of Rodier J. [2]. The results are expressed in Celsius degrees.

The $\mathrm{pH}$ is measured with a $\mathrm{pH}$ meter-an electrometric model (H19024 microcomputer $\mathrm{pH}$ meter). The results are expressed in $\mathrm{pH}$ units.

The electric conductivity is measured with a multirange laboratory conductivity meter of type H19033. The results are given in $\mu \mathrm{S} / \mathrm{cm}$.

The Dissolved Oxygen (DO) is measured in the laboratory in accordance with Winkler method described by Rodier J. [2]. The results are expressed in oxygen concentration $(\mathrm{mg} / \mathrm{L})$ and the percentage of saturation, which is the ratio of oxygen concentration and the solubility of oxygen at the water temperature when the sample was taken.

Mixed in accordance with the method of cadmium reduction, the level of nitrates, expressed in $\mathrm{mg} / \mathrm{L}$ of $\mathrm{NO}_{3}$ is calculated by the difference of the levels of nitrates and nitrites. The calibration range of the nitrates is shown in Table 1 . 
Table 1 Calibration range of nitrates.

\begin{tabular}{lllllllll}
\hline \multicolumn{1}{c}{ Standard solutions $(\mathrm{mg} / \mathrm{L})$} \\
\hline $\begin{array}{l}\text { Nitrates } \\
\left(\mathrm{NO}_{3}^{-}\right)\end{array}$ & 5 & 10 & 20 & 40 & 60 & 80 & 100 & 120 \\
\hline
\end{tabular}

\subsection{Statistical Analysis}

The results obtained are treated using a descriptive statistical analysis method of means and standard deviations.

\section{Results}

\subsection{Air and Water Temperatures}

The air temperature measured at the level of Rhumel river reaches a maximum of $39{ }^{\circ} \mathrm{C}$ (site Rh4), and a minimum of $7^{\circ} \mathrm{C}$ (site $\mathrm{Rh} 2$ ). The average temperature for the three sites is $21.5^{\circ} \mathrm{C}$. The water temperature reaches a maximum of $29{ }^{\circ} \mathrm{C}$ at the site $\mathrm{Rh} 4$ and a minimum of $6^{\circ} \mathrm{C}$ at the site $\mathrm{Rh} 2$. On the other hand, at the level of the two dams, the minimum air temperature is $7{ }^{\circ} \mathrm{C}$ at the site $\mathrm{Bg} 1$, and the maximum is $31^{\circ} \mathrm{C}$ at the site $\mathrm{Bg} 5$. The maximum water temperature is $28^{\circ} \mathrm{C}(\mathrm{Bg} 1)$, and the minimum is $6{ }^{\circ} \mathrm{C}(\mathrm{Bg} 5)$.

\section{$4.2 p H$}

The Rhumel river is characterized by alkaline waters. The $\mathrm{pH}$ varies between 7.2 and 8.4. The most elevated $\mathrm{pH}$ value (8.4) is measured at the site $\mathrm{Rh} 2$. The lower value (7.2) is measured at the site Rh3. At the level of the waters of the dams, the highest $\mathrm{pH}$ (8.36) is measured at site $\mathrm{Bg} 1$ and the lowest $\mathrm{pH}$ (7.4) is measured at the same site (Fig. 1).

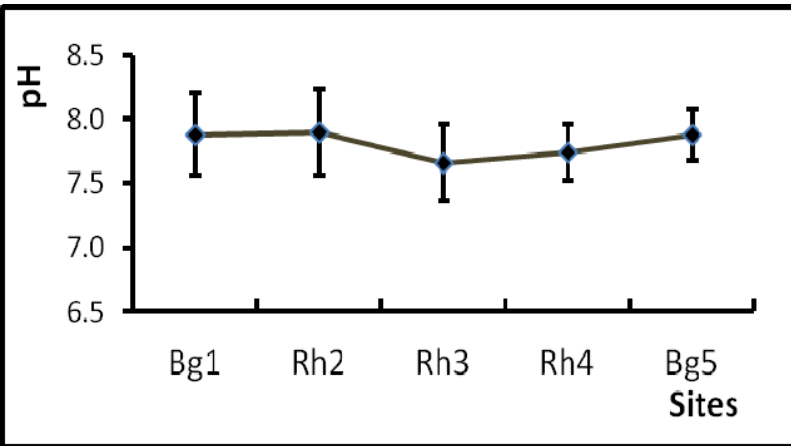

Fig. 1 pH (mean +/- standard deviation) of the dams Hammam Grouz (Bg1), Beni Haroun (Bg5) and Rhumel river (Rh2, $R h 3$ and $R h 4)$.

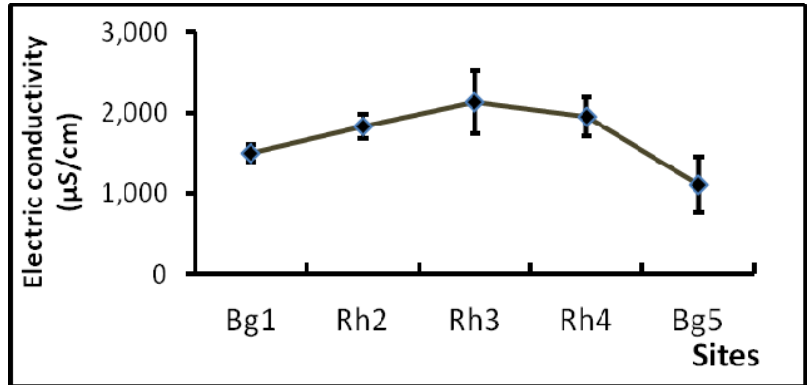

Fig. 2 Electric conductivity (mean +/- standard deviation) of the dams Hammam Grouz (Bg1), Beni Haroun (Bg5) and Rhumel river (Rh2, $R h 3$ and $R h 4)$.

\subsection{Electric Conductivity (EC)}

The electric conductivity is characterized by great variations at the level of the site Rh3 compared to the other sites. For Rhumel river, the weakest EC value is $1,400 \mu \mathrm{S} / \mathrm{cm}$ registered at the level of the two sites-Rh2 and Rh3, and the highest value registered is $3,000 \mu \mathrm{S} / \mathrm{cm}$ at the site $\mathrm{Rh} 3$. For the two dams, the weakest EC value is $800 \mu \mathrm{S} / \mathrm{cm}$ registered at the site $\mathrm{Bg} 5$, and the highest value is $1,810 \mu \mathrm{S} / \mathrm{cm}$ registered at the same site (Fig. 2).

\subsection{Dissolved Oxygen (DO)}

The contents of dissolved oxygen vary greatly. The percentage of saturation is some times more expressive than the content in $\mathrm{mg} / \mathrm{L}$. A maximum saturation $100 \%(10.50 \mathrm{mg} / \mathrm{L})$ was registered at the three sites of Rhumel, while a minimum of $42.20 \%$ (3.79 $\mathrm{mg} / \mathrm{L})$ was registered at the site Rh3. For the waters of the dams, a maximum of $117 \%(12.20 \mathrm{mg} / \mathrm{L})$ and a minimum of $44 \%(4.40 \mathrm{mg} / \mathrm{L})$ were registered at the site Bg5 (Fig. 3).

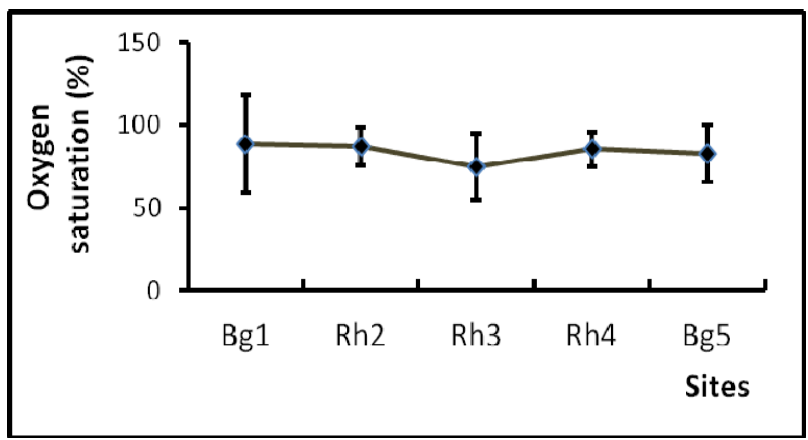

Fig. 3 Percentage of oxygen saturation (mean +/- standard deviation) of the dams Hammam Grouz (Bg1), Beni Haroun (Bg5) and Rhumel river (Rh2, Rh3 and Rh4). 


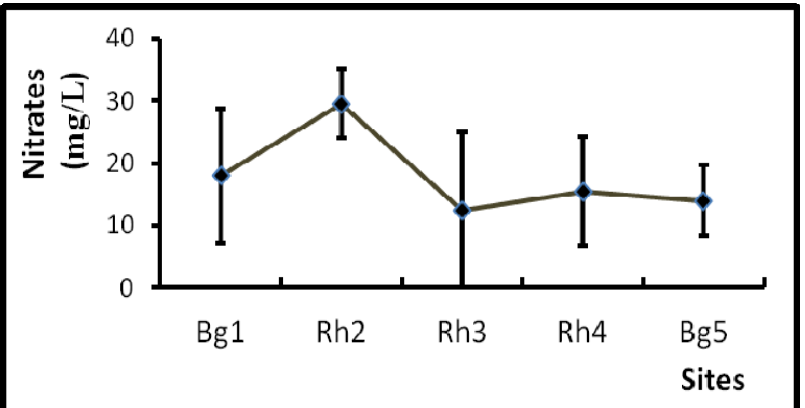

Fig. 4 Nitrates content (mean +/- standard deviation) of the dams Hammam Grouz (Bg1), Beni Haroun (Bg5) and Rhumel river (Rh2, $R h 3$ and $R h 4)$.

\subsection{Nitrates}

The maximum concentration of nitrates in the waters of Rhumel river is $43 \mathrm{mg} / \mathrm{L}$, registered at the site $\mathrm{Rh} 2$, and the minimum concentration is $19 \mathrm{mg} / \mathrm{L}$, registered at the site Rh3. For the waters of the two dams, the maximum concentration of nitrates is $37 \mathrm{mg} / \mathrm{L}$ and 3 $\mathrm{mg} / \mathrm{L}$, registered at the same site Bg1 (Fig. 4).

\section{Discussion}

The temperature is a function of time and location. The water temperature depends on the ambient environment. In fact, the temperature is an important ecological factor that has strong influence on the physico-chemical properties of the aquatic ecosystems [3]. It conditions the possibilities of the development of the aquatic species by regulating the duration of their biological cycle [4].

All sites experience the temperature increase with the evolution of the seasons, from winter to spring. The state of the sites is influenced by this parameter, consequently, the lotic ecosystem of Rhumel, experiences important thermal variations compared to the lentic ecosystem of the two dams.

The increase in temperature is always accompanied by a change in density, an increase of the saturated water vapor pressure at the surface (evaporation), and a decrease in oxygen solubility. The deficiency in oxygen solubility could lead to a critical situation translated in the accumulation of wastes such as: $\mathrm{SH}_{2}$, $\mathrm{SO}_{2}, \mathrm{CH}_{4}$ and organic matter. Thus, the fermentation phenomena are facilitated by the increase in temperature resulting in nauseous odors from the waterways and the dams [5]. Based on the evaluation grid of the general quality of water adopted in France [6], the waters of Rhumel river and those of the two dams (Hammam Grouz and Beni Haroun) are on normal quality and average good (classes 1A, 1B and 2) according to their temperatures.

The $\mathrm{pH}$ represents the level of acidity or alkalinity of the aquatic medium $[3,4]$. A pH range between 6 and 9 is favorable for the development of the aquatic fauna and flora. In general, the $\mathrm{pH}$ of the waters of Rhumel river lies in the weak alkaline range $(\mathrm{pH}=7.5$ to 8 ) with an average $\mathrm{pH}$ value in the range of 8 to 9 according to a classification [7]. This is due to calcareous nature of the geology of the catchment basin bed of Rhumel river. It is important to point out that among the three sites in Rhumel river, the site $\mathrm{Rh} 2$ has a more alkaline $\mathrm{pH}$. This may be attributed to the diverse waste discharges of the municipality of Ain Smara as well as the treated waste waters of the industrial complexes. The waters of the two dams have a basic $\mathrm{pH}$ which probably due to the runoff waters containing diverse sediment.

Based on the evaluation grid adopted in France [6], the quality of the waters of Rhumel river and those of two dams are normal according to their $\mathrm{pH}$ (classes $1 \mathrm{~A}$ and $1 \mathrm{~B})$.

The measurement of the electric conductivity allows the rapid approximate evaluation of the global mineralization of the water. It constitutes a good evaluation of the global concentrations of soluble matters in the water.

The waters of Rhumel river and those of the two dams are characterized by an excessively strong mineralization according to the classification adopted by Nisbet and Verneaux [8] (i.e., $\mathrm{CE}>1,000 \mu \mathrm{S} / \mathrm{cm}$ ). This is the case for all the sites selected for sample collection. Between sites Rh2 and Rh3, Rhumel river receives waste discharges released from the industrial zone (Palma) and the city of Constantine, 
consequently, leading to an elevated EC in the site $\mathrm{Rh} 3$ compared to the site Rh2. In comparison, these findings are consistent and confirm the results of earlier work [9].

Based on the evaluation grid of the quality of waste water adopted in France [8], the diverse samples collected could be qualified based on the rate of oxygen: the quality of waters of Rhumel river is in general good (class 1B) to fair (class 2), and the quality of the waters of the dams is on average good (class 1B).

The nitrates constitute the final stage of organic nitrogen oxidation. Their presence in polluted water attests to the fact that the process of auto-purification has already taken place. The elevated content of nitrates registered at the site $\mathrm{Rh} 2$ could be due to soil leaching. The minimum value of nitrates measured at the site Rh3 could be attributed especially to the presence of nitrogen in the form of ammonium.

The results obtained for the waters of the dams showed a maximum level of nitrates content registered at the site Bg1, especially of agricultural origin. Such content could be linked the spring period when the vegetation is abundant and the elevated temperature promotes the mineralization of organic nitrogen. Overall, based on OMS recommendations [10], the waters of the Rhumel and the two dams are of acceptable quality according to their nitrates content (class 2).

\section{Conclusions}

Rhumel river, one of the water resources of great importance in a region of Constantine is subject to great demographic and industrial demands. The commissioning of the two dams Hammam Grouz and Beni Haroun has led to a water reserve that must be preserved.

The ecologic study of the water streams of the Rhumel as well as the waters of the two dams (Hamman Grouz and Beni-Haroun) has certainly provided evidence of the danger posed by the urban and industrial waste discharges on the physico-chemical quality of these waters. In addition, it provides further evidence of the scale of the pollution caused by these waste discharges.

The results obtained through the diverse parameters measured following the physico-chemical approach show cases of perturbations reflected by the whole set of parameters: a seasonal air temperature which determines the water temperature, a $\mathrm{pH}$ with an alkaline tendency (not exceeding 9), an electric conductivity which is in general elevated. Subsequently, these results reflect an excessive mineralization, an increase in the level of dissolved oxygen which implies an advanced process of auto-purification, and a striking increase of nitrates contents casting a mediocre quality of the analyzed waters.

Thus, the water quality has deteriorated in view of the perturbations it has suffered in spite of the collection and treatment of the wastewaters in the purification station of Ibn Ziad. The waste discharges released are responsible for all kind of changes of the physico-chemical quality of the waters. For this reason, the whole set of parameters previously mentioned cast a fair quality of the waters of the two dams of Hammam Grouz and Beni Haroun, and fair to poor quality of the waters of Rhumel river. Therefore, based on the contents of nitrates and phosphates, the pollution level of the Rhumel waters are striking and must be controlled.

\section{References}

[1] Afri-Mehennaoui, F. Z. 1998. "Contribution to the Physico-Chemical and Biological Study of Oued Kébir-Rhumel and Its Principal Tributaries." Master thesis, University Mentouri of Constantine.

[2] Rodier, J., Bazin, C., Broutin, J. P., Champsaur, H., and Rodi, L. 2005. The Analysis of Water, Natural Waters, Stagnant Waters and Sea Waters, 8th Edition. Paris: Dunod.

[3] Ramade, F. 2002. Encyclopedic Dictionary of Ecology and Environmental Sciences, 2nd Edition. Paris: Dunod.

[4] Angelier, E. 2003. Ecology of Running Waters, Technique and Documentation Edition. Paris: Lavoisier. 

Rhumel River, Hammam Grouz and Beni Haroun Dams

[5] Bremond, R., and Vuichard, R. 1973. The Parameters of the Quality of Waters. Paris: The French Documentation.

[6] Monod, J. 1989. Record of Water Techniques, 9th Edition. Paris: Degrement.

[7] Benlatreche, M. C., and Benslimen, S. 2002. "Evaluation of the Levels of Organic and Metallic Pollution $(\mathrm{Zn}, \mathrm{Cu}$ and Ni) in L'Oued Rhumel and Its Tributary Oued Boumerzoug in Urban Area (Constantine).” Master thesis, University Mentouri of Constantine.

[8] Nisbet, N., and Verneaux, J. 1970. "Chemical Components of Running Waters; Discussion and
Proposal of Classes as Basis for Interpretation of Chemical Analyses." Limnology Records 6 (2): 161-190.

[9] Leynaud, G., and Verrel, J. L. 1980. "Modification of the Aquatic Environment under the Influence of Pollution." In The Pollution of Continental Waters, Impact on the Aquatic Biocenosis, edited by Pesson, P. Paris: Gauthier-Villars.

[10] World Health Organization (WHO). 1989. Toxicological Evaluation of Certain Food Additives and Contaminants. 3rd Report of the FAO/WHO, Technical Report. 